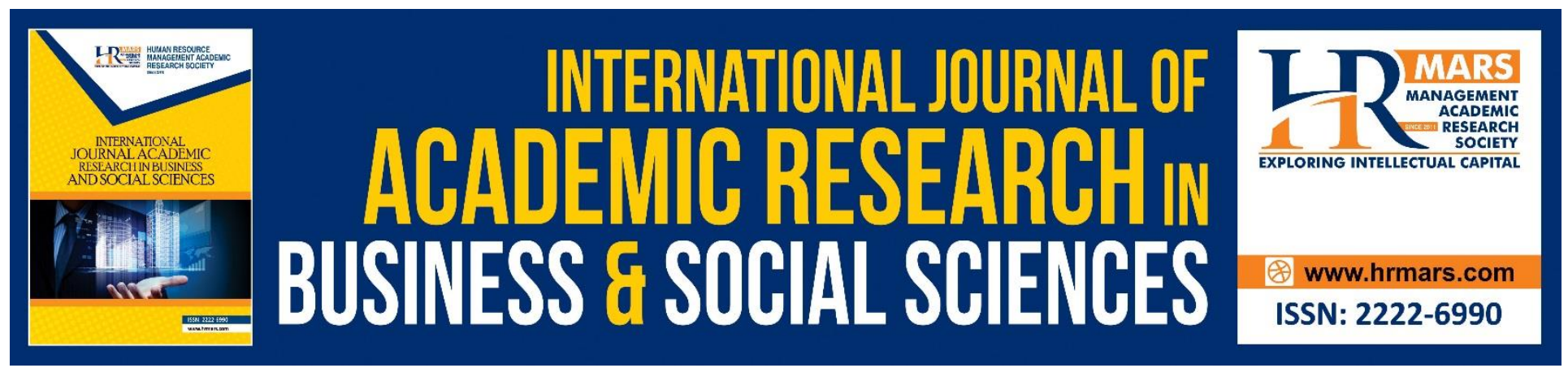

\title{
Does Contemporary Performance Measurement Systems Effect Co-Operatives Managerial Performance: Evidence from Malaysia
}

Mohd Shahron Anuar Said, Sharul Effendy Janudin

To Link this Article: http://dx.doi.org/10.6007/IJARBSS/v10-i7/7429

DOI:10.6007/IJARBSS/v10-i7/7429

Received: 05 April 2020, Revised: 10 May 2020, Accepted: 11 June 2020

Published Online: 29 July 2020

In-Text Citation: (Said, 2020)

To Cite this Article: Said, M. S. A. S. E. J. (2020). Does Contemporary Performance Measurement Systems Effect Co-Operatives Managerial Performance: Evidence from Malaysia. International Journal of Academic Research in Business and Social Sciences, 10(7), 383-394.

\section{Copyright: (C) 2020 The Author(s)}

Published by Human Resource Management Academic Research Society (www.hrmars.com)

This article is published under the Creative Commons Attribution (CC BY 4.0) license. Anyone may reproduce, distribute, translate and create derivative works of this article (for both commercial and non-commercial purposes), subject to full attribution to the original publication and authors. The full terms of this license may be seen at: http://creativecommons.org/licences/by/4.0/legalcode

Vol. 10, No. 7, 2020, Pg. 383 - 394

Full Terms \& Conditions of access and use can be found at http://hrmars.com/index.php/pages/detail/publication-ethics 


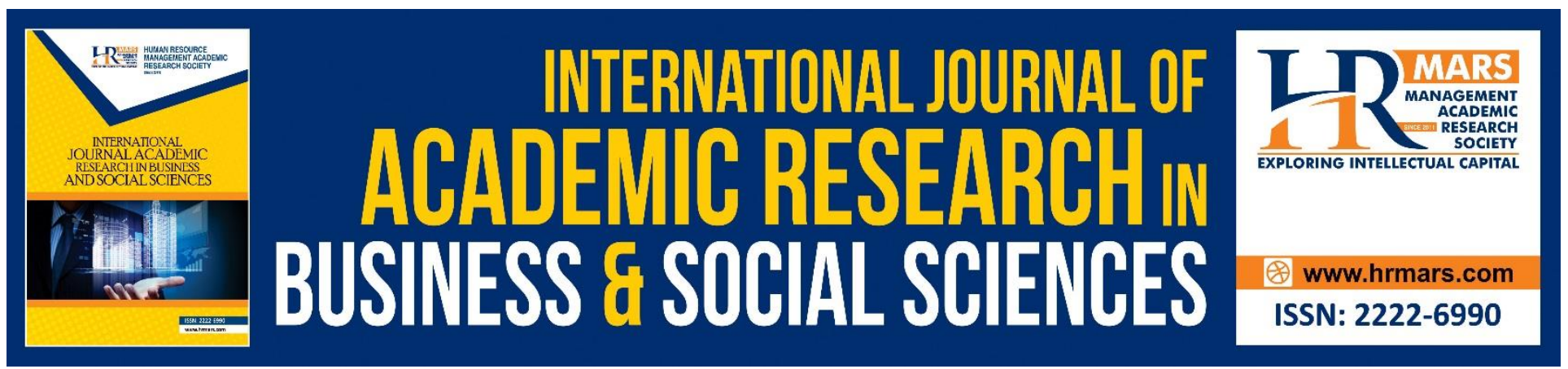

\title{
Does Contemporary Performance Measurement Systems Effect Co-Operatives Managerial Performance: Evidence from Malaysia
}

\author{
Mohd Shahron Anuar Said, Sharul Effendy Janudin \\ Faculty of Management and Economics, Universiti Pendidikan Sultan Idris, Perak, Malaysia
}

\begin{abstract}
Performance measurement system (PMS) has been recognized as a management tool that enables the organization to coordinate their objective and strategic goals. Contemporary PMS consists of three elements: comprehensive, strategic and dynamic, which requires adaption of environmental changes in the organization. Despite the important roles played by the co-operatives movements in economic and social of community, previous studies found weakness in governance practices and lack of numbers of successful co-operatives. Thus, this study examines the effect of contemporary PMS on co-operatives managerial performance. The result of this study indicates that contemporary PMS has a significant effect on the co-operatives managerial performance. The implication of the study draws an important role of the co-operatives to explore on the value added activities that could reflect their efficiency in managing their co-operatives. Hence, the enhancement of human capital resources is crucial such as co-operatives management which eventually leads to sustainable competitive advantage. This study contributes to the research and management practices on the importance of contemporary PMS in co-operatives by delving into its effect on managerial performance.
\end{abstract}

Keywords: Performance Measurement System, Managerial Performance, Co-operatives Management, Co-operatives.

\section{Introduction}

There have been an increase numbers of studies concerning performance measurement system (PMS) and their components in a variety of perspectives. There are at least four disciplines namely operations management, accounting, information systems and operations research which draw contribution of studies in the field of PMS (Burgess, Ong, \& Shaw, 2007). Hopper and Bui (2016) point out over the past 25 years, performance measurement and rewards have been most frequently investigated in management accounting research. The use of PMS is suggested to facilitate effective strategy implementation and enhancing organizational performance. Performance measurement and management would help to create organization alignment, enabling prediction and optimization resources allocation, and supporting monitoring and control (Bourne, Franco-Santos, Micheli, \& 
INTERNATIONAL JOURNAL OF ACADEMIC RESEARCH IN BUSINESS AND SOCIAL SCIENCES Vol. 10, No. 7, July, 2020, E-ISSN: 2222-6990 @ 2020 HRMARS

Pavlov, 2018). PMS is one of the tools for organization to communicate their achievement to stakeholders.

Although there are many studies on the PMS in a variety of perspectives, however, there is lack of study specifically on PMS practices amongst co-operatives (Sharul, Farahaini, \& Shafeeza, 2016). Cooperatives sector has been classified as the third contributing engine to the Malaysian economic development as well as the public and private sectors (Azmah, Fatimah, Rohana, \& Rosita, 2012; Intan, Maslinawati, \& Azizah, 2013; Hafizah, Mahazril', Husin, Hajar, 2016). Co-operatives has been recognized as an entity that can benefit their members and help to improve the standard living of the community, especially for the low and middle income groups. However, the growth of the cooperatives sector substantially behind the private sector has raised concerns about the factors which can help to improve the performance of co-operatives sector in Malaysia. Hence, this study is conducted to investigate and discuss the effect PMS on co-operatives managerial performance. The specific objective of this study is:

- To examine the relationship between contemporary PMS towards co-operatives managerial performance.

\section{Literature Review}

\section{Resource-Based Theory}

This study is underpinned by resource-based theory to examine the PMS effect on managerial performance. This theory emphasizes the use of available organizational resources to generate sustained competitive advantages. It can be obtain by implementing strategies that emphasize the internal strengths, react to environmental opportunities, neutralizing external treats and evade external weaknesses (Barney, 1991).

Resources within an organization can be conveniently classified into three categories, such as physical capital resources, human capital resources and organizational capital resources (Barney, 1991). This study focuses to examine of utilizing human capital resources (co-operatives management) and organizational capital resources (performance measurement system) to achieve desired managerial performance. Individual behavior and cognitions in developing human capital resources is importance, hence to create the competitive advantage for the organization (Alvarez \& Busenitz, 2001; Castanias \& Helfat, 2001).

\section{Contemporary Performance Measurement System}

PMS is a set of metrics used to measure the efficiency and effectiveness of actions (Neely, Gregory, \& Platts, 2005). It can be used as management control tool that are capable of coordinating organizational strategic objectives and management efforts, ensure achievement of key success indicators and justify resource utilization, and provide feedback for future improvement (Amizawati, 2014). The limitation of traditional PMS, forcing the contemporary PMS are suggested as a bridge of the gap with consideration of the changes (Goshu \& Kitaw, 2017).

Hall (2008) clarifies PMS is more comprehensive when include a broad set of measures that cover different parts of the operations in the organization, and integrate that measures with strategy. Burney \& Widener (2007) stated strategic PMS that are closely related to organizational strategy will 
reflect better in strategic objectives. Recent studies have focused on the role of strategic PMS as a tools for effective strategy implementation (Gimbert, Bisbe, \& Mendoza, 2010). Understanding dynamic of performance measurement more thoroughly, using up-to-date measure would lead to efficient strategy implementation (Korhonen, Laine, \& Suomala, 2013).

Changes in economic, social, technology and philosophy are causing PMS change to be contemporary. In parallel with recent business environment, performance measurement design need be refined to new function such as continuous improvement, organization learning and change management (Pinheiro, Gouvea, Angelis, \& Munik, 2013). Franco-Santos, Lucianetti, and Bourne (2012) stated that a contemporary PMS consist of financial and non-financial performance measures linked to organization strategy. While, Henri (2010) raise the issue of periodic review of performance indicators by organization to reflect environmental changes. Therefore, contemporary PMS should apply three elements; comprehensive, strategic and dynamic (Sharul \& Ruhanita, 2016).

\section{Managerial Performance}

An organization performance is closely linked to how successful management to formulate and execute its business strategy. A good and responsible management can drive the organization to a better level, and achieve the desired goal and performance. The managers' objective output need to be measure as an indicator of organizational effectiveness (Hosie \& Nankervis, 2016). Therefore, management needs to be aware of any changes that occur within and outside the organization.

In addition to financial measures, Lau (2015) emphasizes that non-financial measure as performance evaluation criteria is positively related to managerial performance. An understanding of how performance measurement can influence managerial performance is crucial to enabling an organization gain sustained competitive advantage. Dragomir and Panzaru (2014) emphasize that the managerial performance is a fundamental of any self-respecting organization. In addition, they stated the managers' needs to adapt the demands of the very dynamic business environment, which can directly affect the individual productivity as well as groups they supervise, hence can influence of their performance.

\section{Performance Measurement System and Managerial Performance}

Instead of organization performance, the effectiveness of PMS can also be studied from the perspective of the individual within the organization. PMS have been found to affect at all level of the organization, however, more studied focused on the organization performance (Gimbert et al., 2010). Despite that, there is growing of study exploring the impact of contemporary PMS on managerial performance (Franco-Santos et al., 2012), either directly or indirectly affect.

The findings of previous studies show that performance measurement system can have direct or indirect relationship effect on managerial performance. The findings of Hall (2011) study indicates that comprehensive performance measurement system affect to improve management learning variables, which indirectly positively affect managerial performance. Similarly, Lau (2015) study found that non-financial item performance measures have a significant impact on managerial performance through mediate variable of role clarity. While, Sharul and Nadhirah (2017) study shows that there is 
INTERNATIONAL JOURNAL OF ACADEMIC RESEARCH IN BUSINESS AND SOCIAL SCIENCES Vol. 10, No. 7, July, 2020, E-ISSN: 2222-6990 @ 2020 HRMARS

a significant direct relationship between strategic PMS and managerial work performance of cooperative management.

\section{Hypothesis Development}

Previous literature in section before stated that contemporary PMS can be based on three elements; comprehensive, strategic and dynamic, and that have an effect on the relationship with managerial performance. Therefore, as illustrated in Figure 1, this study proposes a conceptual model based on the above mentioned literature.

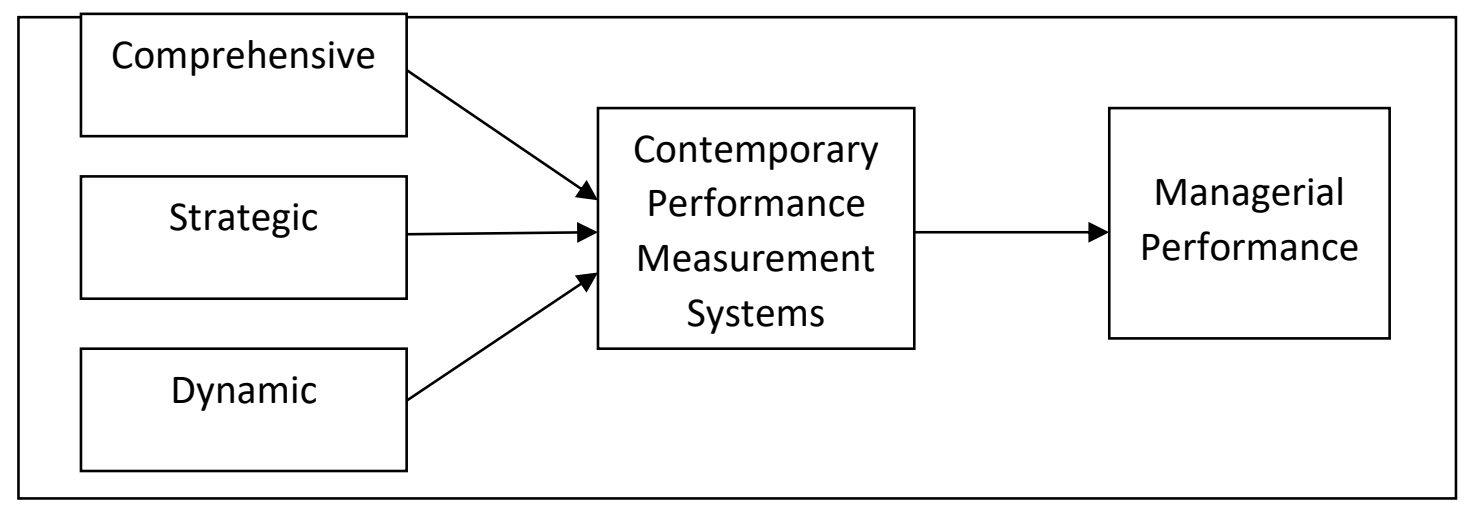

Hence, hypothesis in this study is developed as:

$\mathrm{H} 1$ : Contemporary performance measurement system has positive effect on managerial performance

\section{Methodology}

The study employs a sample of individual management staff as the unit to be analyzed. Management staff comprises of manager and executive officers heading a department or units in top 100 best cooperatives in Malaysia. In addition, 100 best co-operatives are listed under large and medium cluster in which more involved in performance measurement systems (PMS). In this quantitative research, cross-sectional survey was employed for data collection.

A comprehensive PMS was measured with nine items adopted from Hall (2008). A seven-point Likert scale ranged from 1 (not at all) to 7 (to a great extent), was used to measure the level of understanding of the respondents. The instrument developed by Burney and Widener (2007) and Gimbert et al. (2010) were adopted to measure the strategic PMS. The measurement of nine items of strategic PMS instrument were ranged from 1 (strongly disagree) to 7 (strongly agree). Dynamic PMS was measured using four items adopted from Henri (2010) and was ranged from 1 (never) to 7 (regularly). While, nine items adopted from Lau (2015) were used to measure managerial performance, on a seven-point Likert scale ranging from 1 (very low) to 7 (very high).

A total of 574 questionnaires were distributed to target respondents; and 395 completed and usable copies were collected and analyzed. The data were keyed in into SPSS and analyzed using Smart PLS 3.0 (Ringle, Wende, \& Becker, 2015) to assess the hypothesis. 
INTERNATIONAL JOURNAL OF ACADEMIC RESEARCH IN BUSINESS AND SOCIAL SCIENCES Vol. 10, No. 7, July, 2020, E-ISSN: 2222-6990 @ 2020 HRMARS

\section{Findings}

Table 1 shows the demographic profiles of 395 respondents for this study. Respondent consist of 50.4 percent are male and remaining of 49.6 percent are female. More than 80 percent of the respondents were above 31 years old and more than 78 percent have higher education background, diploma holder and above. About 37 percent of the respondents has hold manager's position and above. While, more than 50 percent having length of holding the position less than five years.

Table 1: Respondent's Profile

\begin{tabular}{|c|c|c|c|}
\hline Profile & & Frequency & Percent \\
\hline Gender & $\begin{array}{l}\text { Male } \\
\text { Female }\end{array}$ & $\begin{array}{l}199 \\
196\end{array}$ & $\begin{array}{l}50.4 \\
49.6\end{array}$ \\
\hline Age & $\begin{array}{l}21-30 \\
31-40 \\
41-50 \\
>50\end{array}$ & $\begin{array}{c}75 \\
136 \\
83 \\
101 \\
\end{array}$ & $\begin{array}{l}19.0 \\
34.4 \\
21.0 \\
25.6\end{array}$ \\
\hline Education & $\begin{array}{l}\text { Master } \\
\text { Degree } \\
\text { Diploma/STPM } \\
\text { SPM/SPMV/MCE } \\
\text { PMR/SRP/LCE } \\
\text { Other }\end{array}$ & $\begin{array}{c}27 \\
144 \\
138 \\
81 \\
4 \\
1\end{array}$ & $\begin{array}{c}6.8 \\
36.5 \\
34.9 \\
20.5 \\
1.0 \\
0.3\end{array}$ \\
\hline Position & $\begin{array}{l}\text { CEO } \\
\text { General Manager } \\
\text { Senior Manager } \\
\text { Manager } \\
\text { Assistant Manager } \\
\text { Senior Executive } \\
\text { Executive } \\
\text { Supervisor } \\
\text { Other }\end{array}$ & $\begin{array}{c}7 \\
21 \\
20 \\
97 \\
28 \\
27 \\
115 \\
50 \\
30\end{array}$ & $\begin{array}{c}1.8 \\
5.3 \\
5.1 \\
24.6 \\
7.1 \\
6.8 \\
29.1 \\
12.7 \\
7.6\end{array}$ \\
\hline Position Held & $\begin{array}{l}<5 \\
6-10 \\
11-15 \\
16-20 \\
>20\end{array}$ & $\begin{array}{c}198 \\
101 \\
35 \\
17 \\
44\end{array}$ & $\begin{array}{c}50.1 \\
25.6 \\
8.9 \\
4.3 \\
11.1\end{array}$ \\
\hline
\end{tabular}

Measurement Model Assessment

Table 2 and table 3 displayed the reflective measurement model assessment. Table 2 demonstrates the internal consistency reliability and convergent validity testing. Composite reliability (CR) was used to assess internal consistency reliability, and average variance extracted (AVE) to assess convergent validity (CV). The result shows indicator loadings of all items had exceeded the recommended value of 0.708 (Hair et al., 2017), except for item bc2 had low loading which requires to be dropped. Moreover, all constructs meet the threshold values for composite reliability ( $C R>0.7)$ and average 
INTERNATIONAL JOURNAL OF ACADEMIC RESEARCH IN BUSINESS AND SOCIAL SCIENCES Vol. 10, No. 7, July, 2020, E-ISSN: 2222-6990 @ 2020 HRMARS

variance extracted (AVE > 0.5). This result confirms at this stage that constructs meet reliability and convergent validity requirement.

Table 3 displayed Heterotrait-Monotrait ratio of correlations (HTMT) criterion to assess discriminant validity. Henseler, Ringle, and Sarstedt (2015) stated the exact threshold level of HTMT is debatable between 0.85 and 0.90 , and both values are acceptable. As shown in Table 2, all the value meets the criterion $\mathrm{HTMT}_{0.90}(\mathrm{HTMT}<0.90)$. Hence, this indicates that requirement of discriminant validity is fulfill, and constructs are empirically distinct.

Table 4 displayed the formative measurement model assessment. It exhibits the findings of collinearity and significance and relevance of the formative indicators testing. Variance inflation factor (VIF) was used to assess collinearity, and outer weight significance to assess significance and relevance of the formative indicators. The result for multi-collinearity between indicators shows all indicators for formative construct were below the threshold value of 5 (VIF < 5) (Hair et al., 2017). Hence, there is no collinearity issue on the formative constructs for the estimation of the partial least square (PLS) path model. In addition, for the significance and relevance of the formative indicators result shows all formative indicators are significant except for dynamic (bc). However, prior research has described the relevance of this indicator for capturing the operationalize definition of contemporary performance measurement system (Sharul \& Ruhanita, 2016). Therefore, this dynamic indicator is retained in the formative construct.

Table 2: Measurement Model

\begin{tabular}{|c|c|c|c|c|c|}
\hline Construct & Item & Loadings & CR & AVE & CV (AVE > 0.5) \\
\hline \multirow{20}{*}{$\begin{array}{l}\text { Contemporary } \\
\text { Performance } \\
\text { Measurement } \\
\text { System }\end{array}$} & ba1 & 0.874 & \multirow{9}{*}{0.973} & \multirow{9}{*}{0.801} & \multirow{9}{*}{ Yes } \\
\hline & ba2 & 0.876 & & & \\
\hline & ba3 & 0.906 & & & \\
\hline & ba4 & 0.896 & & & \\
\hline & ba5 & 0.886 & & & \\
\hline & ba6 & 0.896 & & & \\
\hline & ba7 & 0.909 & & & \\
\hline & ba8 & 0.899 & & & \\
\hline & ba9 & 0.914 & & & \\
\hline & $\mathrm{bb} 1$ & 0.868 & \multirow{9}{*}{0.969} & \multirow{9}{*}{0.776} & \multirow{9}{*}{ Yes } \\
\hline & $\mathrm{bb} 2$ & 0.852 & & & \\
\hline & bb3 & 0.881 & & & \\
\hline & bb4 & 0.910 & & & \\
\hline & bb5 & 0.882 & & & \\
\hline & bb6 & 0.886 & & & \\
\hline & bb7 & 0.904 & & & \\
\hline & $\mathrm{bb} 8$ & 0.867 & & & \\
\hline & bb9 & 0.875 & & & \\
\hline & bc1 & 0.869 & \multirow{2}{*}{0.908} & \multirow{2}{*}{0.766} & \multirow{2}{*}{ Yes } \\
\hline & bc3 & 0.894 & & & \\
\hline
\end{tabular}


INTERNATIONAL JOURNAL OF ACADEMIC RESEARCH IN BUSINESS AND SOCIAL SCIENCES Vol. 10, No. 7, July, 2020, E-ISSN: 2222-6990 @ 2020 HRMARS

\begin{tabular}{|l|c|l|l|l|l|}
\hline & bc4 & 0.862 & & & \\
& e1 & 0.873 & & & \\
Managerial & e2 & 0.890 & & & \\
e3 & 0.871 & & & \\
Performance & e5 & 0.868 & & & \\
& e6 & 0.863 & 0.964 & 0.748 & \\
& e7 & 0.814 & & & \\
& e8 & 0.897 & & & \\
& e9 & 0.835 & & & \\
\hline
\end{tabular}

*Item bc2 were dropped due to low loading value <0.708 (Hair et al., 2017)

*ba (comprehensive); bb (strategic); bc (dynamic)

Table 3: HTMT Criterion

\begin{tabular}{|l|c|c|c|}
\hline & Comprehensive & Strategic & Dynamic \\
\hline Comprehensive & - & & \\
\hline Strategic & 0.898 & - & \\
\hline Dynamic & 0.695 & 0.717 & - \\
\hline
\end{tabular}

Criteria: Discriminant validity is established at HTMT 0.85 or $H T M T_{0.90}$

Table 4: Measurement Properties for Formative Construct

\begin{tabular}{|l|l|c|c|c|c|}
\hline Construct & \multicolumn{1}{|c|}{ Items } & Weights & VIF & $\begin{array}{c}\text { t-value } \\
\text { weights }\end{array}$ & Sig \\
\hline $\begin{array}{l}\text { Contemporary } \\
\begin{array}{l}\text { Performance } \\
\text { Measurement }\end{array}\end{array}$ & $\begin{array}{l}\text { Comprehensiv } \\
\text { System }\end{array}$ & 0.498 & 4.227 & $3.210^{* *}$ & 0.001 \\
\cline { 2 - 6 } & Strategic & 0.412 & 4.417 & $2.708^{* *}$ & 0.004 \\
\cline { 2 - 6 } & Dynamic & 0.166 & 1.825 & 1.487 & 0.069 \\
\hline
\end{tabular}

Note: $t$-value $>1.96^{* *}$

\section{Structural Model Assessment}

Table 5 presents the outcome of lateral collinearity test. The result shows inner VIF value is less than 5 , indicating lateral collinearity is not an issue in this model (Hair et al., 2017). Table 6 demonstrates the assessment of the path coefficient and quality of the model. The result shows to have $t$-value more than 1.645, thus the relationship is significant and positively related between contemporary PMS and managerial performance. Hence, the hypothesis is supported.

Meanwhile, the $R^{2}$ (coefficient of determination) value of 0.322 is above the 0.26 value as suggested by Cohen (1988) cited in Ramayah et al. (2018), which indicate a substantial model. The effect size $\left(f^{2}\right)$ is also being assessed. The $f^{2}$ value 0.476 is above 0.35 values as guided by Cohen (1988) cited in Ramayah et al. (2018), in which can be describe that contemporary performance measurement system has a substantial effect size in producing the $\mathrm{R}^{2}$ for managerial performance. Meanwhile the predictive relevance values of 0.310 is larger than 0 , indicating that the contemporary performance 
INTERNATIONAL JOURNAL OF ACADEMIC RESEARCH IN BUSINESS AND SOCIAL SCIENCES

Vol. 10, No. 7, July, 2020, E-ISSN: 2222-6990 @ 2020 HRMARS

measurement system is capable to predict the managerial performance as anticipated by $Q^{2}$ using blindfolding procedure (Hair et al., 2017).

Table 5: Lateral Collinearity Assessment

\begin{tabular}{|l|c|}
\hline Construct & Managerial Performance (VIF) \\
\hline $\begin{array}{l}\text { Contemporary Performance Measurement } \\
\text { System }\end{array}$ & 1.000 \\
\hline
\end{tabular}

Table 6: Path Coefficient and Model Quality Assessment

\begin{tabular}{|c|c|c|c|c|c|c|c|c|c|c|}
\hline $\begin{array}{l}\text { Direct } \\
\text { effects }\end{array}$ & Beta & S.E. & t-value & $\begin{array}{c}\mathrm{p}- \\
\text { valu } \\
\mathrm{e}\end{array}$ & $5.0 \%$ & $\begin{array}{c}95.0 \\
\% \\
\end{array}$ & $\begin{array}{c}\text { Decisio } \\
\mathrm{n}\end{array}$ & $\mathrm{R}^{2}$ & $f^{2}$ & $\mathrm{Q}^{2}$ \\
\hline $\begin{array}{l}\text { Contempor } \\
\text { ary }\end{array}$ & & & & & & & & & & \\
\hline Performanc & 0.56 & 0.03 & 14.839 & 0.00 & 0.49 & 0.62 & Suppor & 0.32 & 0.47 & 0.31 \\
\hline $\begin{array}{l}\text { e } \\
\text { Measureme } \\
\text { nt System } \\
--> \\
\text { Managerial } \\
\text { Performanc } \\
\text { e }\end{array}$ & 8 & 8 & $* *$ & 0 & 4 & 3 & ted & 2 & 6 & 0 \\
\hline
\end{tabular}

\section{Discussion and Conclusion}

The finding of present study indicates contemporary PMS has a significant effect on the co-operatives managerial performance. Contemporary PMS were applied with three elements: comprehensive, strategic and dynamic. Therefore, it should comprise of financial and non-financial measures, clearly linked to strategic objective and responsive to changes of environment. The co-operatives management must acknowledge the importance of flexible and realistic PMS in order to sustain and gaining competitive advantage. In the dynamic era of information and technology, the management needs to respond efficiently and effectively. Furthermore, stakeholders' different expectations would affect their judgment, trust and credibility. Therefore, PMS should consider the goal of co-operatives as to meet the collective needs of specific groups related to their social purpose (Moura et al., 2019).

Franco-Santos et al. (2012) stated the contemporary PMS affects to the individual behavior, organizational capabilities and performance outcomes. PMS could influence internal characteristics of an individual such as cognitive style, ways of thinking and motivation (Hall, 2008; Franco-Santos et al., 2012). Hence, PMS design should motivate managers and individual involved. This is very crucial since them representing a group who implements the policies planned in the organization. Besides, to ensure the sustainability of the organization, co-operatives should employ professional managers and staffs. This is a model of successful co-operatives which governed by a good system and managed by professionals. 
INTERNATIONAL JOURNAL OF ACADEMIC RESEARCH IN BUSINESS AND SOCIAL SCIENCES Vol. 10, No. 7, July, 2020, E-ISSN: 2222-6990 @ 2020 HRMARS

This study makes an important contribution in the management accounting literature by providing insights about the roles of PMS in influencing managerial performance in the context of co-operatives in Malaysia. By empirically examining the relationship between PMS and co-operatives managerial performance, this particular study extends the current knowledge of contemporary PMS which integrates the three PMS elements which consists of comprehensive, strategic and dynamic towards co-operatives managerial performance. Findings from this study confirms that resource-based theory (Barney, 1991) underpinning the phenomenon of the present study.

As the current co-operatives sector performance has not achieved its full potential, practicing contemporary PMS would encourage individual performance enhancements which in line with the organization's goals. Meanwhile, the implementation of system, procedure and policy must uphold the co-operatives values, ethical values and co-operatives principles, that makes it valuable and unique human capital resources. Voluntary membership and democratically controlled principles, must been to translate and applied by co-operatives management in designing the PMS inclusively in line to their members' aspiration and co-operatives business' goal. Future studies should consider examining contemporary PMS elements with other cluster of co-operatives and differentiating between the functions. A qualitative approach also is needed for further work to better understand the role of contemporary PMS among the co-operatives management.

\section{References}

Alvarez, S. A., \& Busenitz, L. W. (2001). The entrepreneurship of resource-based theory. Journal of Management, 27(6), 755-775. https://doi.org/10.1177 /014920630102700609

Amizawati, M. A. (2014). Performance measurement system design in service operations: Does size matter? Management Research Review, 37(8), 728-749. https://doi.org/10.1108/MRR-022013-0046

Azmah, O., Fatimah, K., Rohana, J., \& Rosita, H. (2012). Factors influencing cooperative membership and share increment: An application of the logistic regression analysis in the Malaysian cooperatives. World Review of Business Research, 2(5), 24-35.

Barney, J. (1991). Firm resources and sustained competitive advantage. Journal of Management, 17(1), 99-120. https://doi.org/10.1177/014920639101700108

Bourne, M., Franco-Santos, M., Micheli, P., \& Pavlov, A. (2018). Performance measurement and management: A system of systems perspective. International Journal of Production Research, 56(8), 2788-2799. https://doi.org/10.1080/00207543.2017.1404159

Burgess, T. F., Ong, T. S., \& Shaw, N. E. (2007). Traditional or contemporary? The prevalence of performance measurement system types. International Journal of Productivity and Performance Management, 56(7), 583-602. https://doi.org/10.1108 /17410400710823633

Burney, L., \& Widener, S. K. (2007). Strategic performance measurement systems, job-relevant and managerial behavioral responses - Role stress and performance. Behavioral Research in Accounting, 19, 43-69. https://doi.org/10.2308 /bria.2007.19.1.43

Castanias, R. P., \& Helfat, C. E. (2001). The managerial rents model: Theory and empirical analysis. Journal of Management, 27(6), 661-678. https://doi.org/10.1177 /014920630102700604

Cohen, J. (1988). Statistical power analysis for the bahavioral science ( $2^{\text {nd }}$ edition). Hillsdale, NJ: Lawrence Erlbaum Associates.

De Lima, P. E., Da Costa, G. S. E., Angelis, J. J., \& Munik, J. (2013). Performance measurement systems: 
INTERNATIONAL JOURNAL OF ACADEMIC RESEARCH IN BUSINESS AND SOCIAL SCIENCES

Vol. 10, No. 7, July, 2020, E-ISSN: 2222-6990 @ 2020 HRMARS

A consensual analysis of their roles. International Journal of Production Economics, 146(2), 524542. https://doi.org/10.1016/j.ijpe.2012.05.007

Dragomir, C., \& Panzaru, S. (2014). The managerial performance. Review of General Management, 19(1), 43-54.

Franco-Santos, M., Lucianetti, L., \& Bourne, M. (2012). Contemporary performance measurement systems: A review of their consequences and a framework for research. Management Accounting Research, 23(2), 79-119. https://doi.org/10.1016 /j.mar.2012.04.001.

Effendy, S. J., Farahaini, M. H., \& Shafeeza, N. Z. (2016). Developing contemporary performance measurement system performance model for co-operatives in Malaysia: Is it necessary? International Journal of Academic Research in Business and Social Sciences, 6(11), 436-448. https://doi.org/10.6007/IJARBSS/v6-i11/2415

Effendy, S. J., \& Nadhirah, I. (2017). The relationship between strategic performance measurement system and managerial work performance of co-operatives in Malaysia. International Journal of Academic Research in Business and Social Sciences, 7(10), 498-506. https://doi.org/10.6007/IJARBSS/v7-i10/3396

Effendy, S. J., \& Ruhanita, M. (2016). Performance measurement system in Malaysian public research university: Is it contemporary? International Journal Management in Education, 10(3), 219-233. https://doi.org/10.1504/IJMIE.2016.077505

Gimbert, X., Bisbe, J., \& Mendoza, X. (2010). The role of performance measurement systems in strategy formulation processes. Long Range Planning, 43, 477-497. https://doi.org/10.1016/j.Irp.2010.01.001

Goshu, Y. Y., \& Kitaw, D. (2017). Performance measurement and its recent challenge: A literature review. International Journal of Business Performance Management, 18(4), 381-402. https://doi.org/10.1504/IJBPM.2017.087103

Hafizah, H. A. K., Mahazril' Aini, Y., Husin, A., \& Hajar, S. A. B. A. (2016). Factors affecting performance of co-operatives in Malaysia. International Journal of Productivity and Performance Management, 65(5), 641-671. https://doi.org/10.1108/IJPPM-05-2014-0077

Hair, J. F. Jr., Hult, G. T. M., Ringle, C. M., \& Sarstedt, M. (2017). A Primer on Partial Least Square Structural Equation Modeling (PLS-SEM): Second Edition. California, United States of America: SAGE Publications, Inc.

Hall, M. (2008). The effect of comprehensive performance measurement systems on role clarity, psychological empowerment and managerial performance. Accounting, Organizations and Society, 33, 141-163. https://doi.org/10.1016/j.aos.2007.02.004

Hall, M. (2011). Do comprehensive performance measurement systems help or hinder managers' mental model development? Management Accounting Research, 22, 68-83. https://doi.org/10.1016/j.mar.2010.10.002

Henri, J.-F. (2010). The periodic review of performance indicators: An empirical investigation of the dynamism of performance measurement systems. European Accounting Review, 19(1), 73-96. https://doi.org/10.1080/09638180902863795

Henseler, J., Ringle, C. M., \& Sarstedt, M. (2015). A new criterion for assessing discriminant validity in variance-based structural equation modeling. Journal of the Academy of Marketing Science, 43(1), 115-135. https://doi.org/10.1007/s11747-014-0403-8

Hopper, T., \& Bui, B. (2016). Has management accounting research been critical? Management Accounting Research, 31, 10-30. https://doi.org/10.1016/j.mar.2015.08.001 
INTERNATIONAL JOURNAL OF ACADEMIC RESEARCH IN BUSINESS AND SOCIAL SCIENCES

Vol. 10, No. 7, July, 2020, E-ISSN: 2222-6990 @ 2020 HRMARS

Hosie, P., \& Nankervis, A. (2016). A multidimensional measure of managers' contextual and task performance. Personnel Review, 45(2), 419-447. https://doi.org/10.1108/PR-02-2014-0038

Intan W. O., Maslinawati, M., \& Azizah, A. (2013). Cooperative movements in Malaysia: The issue of governance. International Journal of Social, Educational, Economic and Management Engineering, 7(6), 660-664.

Korhonen, T., Laine, T., \& Suomala, P. (2013). Understanding performance measurement dynamism: a case study. Journal of Management \& Governance, 17(1), 35-58. https://doi.org/10.1007/s10997-012-9217-6

Lau, C. M. (2015). The effects of nonfinancial performance measures on role clarity, procedural fairness and managerial performance. Pacific Accounting Review, 27(2), 142-165. https://doi.org/10.1108/PAR-03-2013-0017

Moura, L. F., De Lima, P. E., Deschamps, F., Van Aken, E., Da Costa, G. S. E., Treinta, F. T., \& Cestari, J. M. A. P. (2019). Designing performance measurement systems in nonprofit and public administration organizations. International Journal of Productivity and Performance Management, 68(8), 1373-1410. https://doi.org/10.1108 /IJPPM-06-2018-0236

Neely, A., Gregory, M., \& Platts, K. (2005). Performance measurement system design: A literature review and research agenda. International Journal of Operations \& Production Management, 25(12), 1228-1263. https://doi.org/10.1108 /01443570510633639

Ramayah, T., Cheah, J., Chuah, F., Ting, H., \& Memon, M.A. (2018). Partial Least Square Structural Equation Modeling (PLS-SEM) using SmartPLS 3.0: An Updated and Practical Guide to Statistical Analysis: Second Edition. Kuala Lumpur, Malaysia: Pearson Malaysia Sdn Bhd.

Ringle, C. M., Wende, S., \& Becker, J. (2015). SmartPLS 3.0. Bonningstedt: SmartPLS. Retrieved from http://www.smartpls.com 